\title{
FORMS AND MECHANISMS OF LAW DISPUTE RESOLUTION USING THE PRINCIPLE OF PANCASILA BASED ON LOCAL WISDOM
}

\author{
Muhammad Taufiq, Sarsiti, and Rindha Widyaningsih \\ Faculty of Law Universitas Jendral Soedirman Purwokerto \\ E-mail: taufiq1960@yahoo.co.id
}

\begin{abstract}
Dispute resolution in the society should be solve by the value of local wisdom. Substantially, the value of local wisdom in Banyumas have synergy with the principle of Pancasila as the source of all law source. This study uses qualitative descriptive study specifications. The test method is done by triangulation of data sources and data were analyzed using content analysis method by way of presenting data in the form of narrative text. The result is there are four types of local wisdom Banyumas which is a resource for the settlement of legal disputes that occur in society that is the tradition cablakal blakasutha/thokmelong, egalitarian, rembugan traditions, and ponco waliko principles. While the forms of alternative dispute resolution is to use models Judge Partikulir, mediation lines, and Settlement Conference. The mechanism is made through rembugan process, the use of a mediator, the institutionalization of dispute resolution, and the execution of the verdict.
\end{abstract}

Keywords: Pancasila, local wisdom, dispute resolution system

\begin{abstract}
Abstrak
Penyelesaian sengketa dalam masyarakat seharusnya diselesaikan berdasarkan nilai kearifan lokal. Secara substansial, nilai kearifan lokal di wilayah Banyumas telah bersinergi dengan asas Pancasila sebagi sumber dari segala sumber hukum. Penelitian ini menggunakan metode kualitatif dengan spesifikasi penelitian deskriptif. Metode uji data dilakukan dengan triangulasi sumber dan analisis data menggunakan content analysis method, dengan bentuk penyajian data berupa teks naratif. Hasil yang diperoleh adalah terdapat empat jenis kearifan lokal Banyumas yang merupakan modal bagi penyelesaian sengketa hukum yang terjadi di masyarakat, yaitu tradisi cablaka/blakasutha/thokmelong, sifat egaliter, tradisi rembugan dan prinsip ponco waliko. Sedangkan bentuk dari alternatif penyelesaian sengketa adalah dengan menggunakan model Hakim Partikulir, jalur mediasi, dan Settlement Conference. Mekanisme yang dilakukan melalui proses rembugan, penggunaan mediator, pelembagaan penyelesaian sengketa dan eksekusi hasil putusan.
\end{abstract}

Kata Kunci: Pancasila, kearifan lokal, sistem penyelesaian sengketa

\section{Introduction}

Indonesia has many local wisdom values. A challenge to develop the concept and theories of cooperative disputes resolution based on the values of local wisdom in Indonesia. How to create patterns and shades of dispute resolution and conflict which is a product of Indonesia. One of interesting local wisdom to be studied is the local wisdom that comes from Banyumas. Local

$\Omega \quad$ This article is the result of research articles with scheme "Penelitian Unggulan Perguruan Tinggi" carried out based on the decision of a number Kept.968/UN23.14/PN. 01.00/2015

1 Otong Rosadi, “Hukum Kodrat, Pancasila Dan Asas Hukum Dalam Pembentukan Hukum Di Indonesia”, Jurnal wisdom of Banyumas are the values which is upheld by Banyumas society, including in the dispute resolution. Value of local wisdom has become law of Banyumas society.

Dispute resolution by featuring local wisdom is still doubted by some people, especially the actors of law emphsizing on the principle of legal certainty. ${ }^{1}$ Local wisdom is regarded as sphere of traditional law and would have diffi-

Dinamika Hukum, Volume 10 No. 3 September 2010, Purwokerto: Faculty of Law, Universitas Jenderal Soedirman, page 279 . 
culty in determining the difference between the use of local wisdom and traditional laws.

The use of local wisdom on a practical level would lead to confusion in the Indonesian legal system because the level of law diversity is vary and there is no uniformity of law in a country. This study aims to find a system of dispute resolution with acculturation the local wisdom values by source of all sources law in Indonesia, which is Pancasila This study aims to find a system of dispute resolution with acculturation the local wisdom values by source of all sources law in Indonesia, Pancasila, so that the certainty, usefulness and legal justice can be achieved. Related to case above, it is a challenge to reform Indonesian legal system to adjust with globalization, obey to the principle, but it can resolve the problems properly and quickly.

\section{Problems}

The problems raised in this research is how are forms of decision and mechanisms for dispute resolution using the principle of Pancasila based on local wisdom?

\section{Research Methods}

The method in this study is using qualitative method with descriptive study specifications. The location of study was done in Banyumas with the method of collecting primary data through interviews with informants that consists of the Banyumas District Court and Purwokerto District Court, Local Government of Law section, public figures and cultural observers, to further the informants were selected using snowball

2 Ilyas, "Kajian Penyelesaian Konflik antar Desa Berbasis Kearifan Lokal di Kabupaten Sigi, Sulawesi Tengah", Jurnal Academika, Vol. 06 No. 01, February 2014, Palu: Faculty of Social and Political Science, Universitas Tadulako, page 1222

3 Galang Asmara, Arba and Yanis Maladi, "Penyelesaian Konflik Pertanahan Berbasis Nilai-Nilai Kearifan Lokal Di Nusatenggara Barat", Jurnal Mimbar Hukum, Vol 22, No. 1 February 2010, Yogyakarta: Faculty of Law, Universitas Gadjah Mada, page 10.

4 Yulianti, Rina and Sri Maharani MTV, "Penyelesaian Sengketa Informal Berbasis Komunitas Adat Terpencil di Kepulauan Kangean", Jurnal Dinamika Hukum, Vol. 12, No. 2, May 2012, page 198.

5 Suprapto, "Revitalisasi Nilai-Nilai Kearifan Lokal bagi Upaya Resolusi Konflik", Jurnal Walisongo, Vol. 21, No. 1, May 2013, Semarang: LP2M, IAIN Semarang, page 20. sampling method. Collecting data is also supported by the various sources of literature as secondary data. The test method is done by triangulation source and data analysis using content analysis method, by forms of presenting data of narrative text, tables or charts.

\section{Discussion}

\section{Banyumas Local Wisdom}

Each region basically has the local wisdom which can be used to resolve disputes and conflicts in society, as well as the results of study about Nosarara Nosabatutu local wisdom in Sigi society, ${ }^{2}$ local wisdom of tao retreat each post in Sasak and Mbajo, ${ }^{3}$ Kangean Islands society, ${ }^{4}$ local wisdom of West Nusa Tenggara, ${ }^{5}$ Siak in Riau, ${ }^{6}$ until Papua ${ }^{7}$ and other regions which showed that society basically has a legal order to resolve conflicts and disputes. In Banyumas there are 4 (four) principles of local wisdoms which can be used as a basis in the preparation of the dispute resolution systems based on Pancasila of local wisdom, namely: first, it is cablaka/blakasuta/thokmelong. Cablaka often interpreted as a character that emphasizes the candor of $\mathrm{Ba}$ nyumas people. ${ }^{8}$ Character of cablaka shows that Banyumas people prefer to express and to think openly based on the reality. Cablaka is the center or core character models of Banyumas people. ${ }^{9}$

The word of blakasuta derived from word of suta which means "child". This cablaka and blakasuta meaning of honesty which is still pure, innocent, or as it is and have not changed. Children basically are more honest compared to adul-

6 Riska Fitriani, "Penyelesaian Sengketa Lahan Hutan Melalui Proses Mediasi di Kabupaten Siak", Jurnal Ilmu Hukum, Vol. 3, No. 1, 2012, Riau: Faculty of Law, Universitas Riau, page 3.

7 Frans P. Kafiar, “Kearifan Lokal Suku Amungme dalam Pengelolaan Sumber Daya Alam dan Lingkungan di Kabupaten Mimika Papua”, Jurnal EKOSAINS, Vol. V No. 1 March 2013, Surakarta: Environmental Studies Program, Universitas Sebelas Maret, page 35.

8 Sugeng Priyadi, 2013, Sejarah Mentalitas Banyumas. Yogyakarta: Ombak, page 7.

9 Sugeng Priyadi, "Cablaka Sebagai Inti Model Karakter Manusia Banyumas”, Jurnal Diksi: Jurnal Ilmiah, Bahasa, Sastra dan Pengajarannya, Vol. 14, No. 1 September 2007, Yogyakarta: Faculty of Language and Arts, Universitas Negeri Yogyakarta, page 13. 
ts. Similar with cablaka and blakasuta. Thokmelong is similar terms meaning. Thokmelong consists of two words, namely thok and melong. Thok means "simple", "mere", "only", whereas melong means "shiny", so thokmelong is defined as "only glossy", meaning that Banyumas people are outspoken as seen in the front of eyes. ${ }^{10}$

Sugeng Priyadi has done extensive study on the culture of Banyumasan. The study concluded that the value of cablaka become a focal point in the cultural system. ${ }^{11}$ Cablaka is regarded as very valuable in in the daily life of Banyumas society. Therefore, cablaka becomes synonymous to the local cultural system Banyumas society.

Second, is the properties of egalitarian. The Central Java language is the ancestor language to the dialects of Banyumasan known as now. Marginal humans usually live in cultural freedoms. Marginal cultural expression is more typical, more free, as it is, rude, and seemed rowdy. Seen from the side of the palace, marginal culture is a culture which rude so if adopted by the palace, the culture must exist smoothing and packaging in order to impress and more prestigious. Marginal culture is a natural tendency for Banyumas people who are always critical and able also want to give another vote against the authorities, both at central and local levels. ${ }^{12}$

Equalization symbol of Banyumas society is seen at the symbol of Punakawan Carub Bawor. That symbol explained that Banyumas people are open minded to the daily life relationship called cablaka or blakasuta. Another puppet figures also show the character and egalitarian character can be found in the figures as Wisanggeni, Antasena, Werkudara, and the clown-servants in a puppet show gagrag of Banyumasan. Local wisdom in the form of egalitarian society makes Banyumas people not segmented by social status and making communal society. People will be more subdue their ego and prevent their

10 Sugeng Priyadi, 2013. op cit, page 10.

11 Sugeng Priyadi, “Orientasi Nilai Budaya Banyumas: antara Masyarakat Tradisional dan Modern", Jurnal Humaniora, Vol. 20, No. 2, June 2008 Edition, Yogyakarta: Faculty of Humanities, Universitas Gadjah Mada, page 159. arrogancy, so they prefer to select a line of disputes resolution peacefully to the egalitarian owned.

Third, is rembugan, rembugan has meaning deciding a case based on mutual agreement without coercion and pressure. Rembugan is known as deliberation to reach a consensus. This tradition sounds cliché and can be said to exist in every region in Indonesia. Therefore, deliberation can be said as One distinctive feature of Indonesia and legitimate in the fourth principle of Pancasila state ideology.

The chronicle of Banyumas has been explained that during the reign of Wargautama I, District Wirasaba under the authority of Kanjeng Sultan Hadiwijaya (Jaka Tingkir) annually obligeted to attend the a great deliberation of kingdom called Pasewakan Ageng conducted in Caitra (March-April). ${ }^{13}$ This tradition illustrates that rembugan tradition or deliberation has been conducted since a long time ago, even in situations monarchy government. This rembugan tradition then applied in Banyumas area which is an area of Pajang authority, then spread to the smallest governments area called village.

Deliberation is an appropriate way for Indonesia, which has high level diversity. Deliberation is able to accommodate the aspirations of the various elements and circles. The parties are more satisfied with the decision taken and felt advantaged. All are entitled to cast their opinions and have the same position in deliberation. Rembugan also strengthens the evidence of egalitarian characteristic held by Banyumas society. Rembugan usually conducts in public spaces, for example in the village meeting hall or community center and done at certain times according to mutual agreement.

Deliberation with cablaka speech reflects the equality of citizens status. There is no differrence social strata which can be used as a reason to approve or reject the idea. Each plan will be taken based on the simple logic of the villagers.

12 Sugeng Priyadi, "Beberapa Karakter Orang Banyumas", Jurnal Bahasa dan Seni, Year 31, No. 1, February 2003 Edition, Malang: Faculty of Letters, Universitas Negeri Malang, page 19

13 Adisarwono, et.al, 1985, Riwayat Banyumas, Solo: Tiga Serangkai, page 38 . 
The nature of cablaka re-establish egalitarian attitude which is a manifestation substantion in Banyumas culture. ${ }^{14}$

Fourth, the principle Ponco Waliko. Discourse of Ponco Waliko can be seen on one of the the historical sites in Banyumas, namely Paseban Sengkala Batur. There are two upright stones placed in the position of the grave marker. Paseban Batur suspected as a meeting place of people earlier times. It also proves that this place is a public space used by people to make deliberation in making decisions and resolving various problems faced.

Placement deliberation locations in places that are considered sacred and holy proves that rembugan or deliberation is serious and has a magical spiritual significance because it could not conduct in random place. Rembugan means high seriousness, so it cannot conduct modest or merely as a formality.

Etymologically, the word of ponco waliko derived from Ponco which means 'five' and Waliko meaningful 'advice'. Ponco waliko contains five basic principles which consists of: a) Kudu tresno marang sepadaning urip (must love to fellow human beings); b) Ora Pareng nerak wewalering negara (must not violate the rules of the country); c) Ora Pareng belonging to sing dudu semestine (may not want something that is not supposed to do); d) Ora Pareng sepata nyepatani (should not curse each other); and e) Ora Pareng ing Ubaya Cidra (must not break a promise).

Fifth, the principle of rerangkenipun ora butuh rewang, ora butuh musuh, butuhe mung kabecikan (continuation is no need help/should be independent, does not need an enemy, only need goodness). This principle gives awareness to not depend on others and is able to become an independent person and live together in goodness.

\section{Forms of Dispute Resolution Using The Prin-} ciple of Pancasila Based on Local Wisdom

Some forms of alternative dispute resolution using principle of Pancasila and based on local wisdom refers to the ADR (Alternative Dispute Resolution), known as The Binding Adjudicative Procedures and The Non-Binding Adjudicative Procedures. The binding adjudicative procedures are specifically divided into 4 (four), namely: litigation, arbitration, mediation-arbitrase and private judges. ${ }^{15}$

Forms of dispute resolution using litigation approach shows that the parties have reached the stage of impasse by not finding an agreement in the deliberation event. The tradition of egalitarian Banyumas society gives the freedom to take the path of litigation on one or both sides are fully respected. The decision to choose the path of disputes resolution is the rights are fully respected.

The model of arbitration resolution on society local wisdom system generally is based on agreements that have been agreed previously. Most of the models of the agreement are done only with trust, which means not being stated in the black and white agreement. The model of fraternity based on the communal and primordial principles assuming people as wonge dewek (their own people/their own brother) causes the emergence of mutual trust when making the agreement. The evidence of the agreement is physically no longer required. The system solution is more based on good faith (good will) from both sides and only relies on witnesses.

Mediatian-Arbitration (Med-Arb) model solution in the local wisdom system is done with the help of mediator who is considered neutral. The mediator usually is the elders or traditional leaders who have positive reputation and agreed upon by both parties to be requested as neutral third party who is able to mediate. The process is done through deliberation and is still being done when the mediator was about to take a deci-

15 Dimiyati, "Penyelesaian Konflik Pertanahan di Provinsi Lampung", Jurnal Keadilan Progresif, Vol. 2 No. 2, September 2011, Yogyakarta: Faculty of Law, Universitas Gadjah Mada, page 194.
14 Teguh Trianton, "Estetika Profetik Ahmad Tohari dalam Khazanah Budaya Cablaka", Jurnal Ibda Jurnal Kebudayaan Islam, Vol. 11, No. 2, July-December 2013, Purwokerto: P3M, Institut Agama Islam Negeri Purwokerto, page 219. 
sion. Cablaka personality which is the characteristic of Banyumas people is one of the positive capital in resolving disputes because they are accustomed to speak as it is and express their feelings more honestly. The attitudes of the open and honest parties are helping the mediator to achieve the peace

Private judge in a more modern life today is usually the justice of the village peace, which is the village chief. The location of dispute resolution is usually in the Village Hall witnessed by the residents. Through this kind of dispute resolution form, a matter does not necessarily always have to go through the state formal court but the disputants are satisfied with the decision and able to accept the decision gracefully.

The non binding adjudicative procedures, these procedures are divided into several types. First, conciliation. The local wisdom Banyumas has accommodated the principle of good will, for example, there is ora pareng sepata nyepatani (should not curse each other) principle in the ponco waliko, which means that keeping your words is an important thing in association governance and communication among human beings. It also means for us to have good selfcontrol in terms of speech from hurting others and causing or worsening the conflicts and disputes. Comprehension of this principle is the basic for the creation of good will for the parties in dispute so that it can bring a clearer atmosphere in reviewing the issue and be able to resolve the dispute without prioritizing negative emotions so that the case can be decided more quickly and beneficial for both parties.

Second, mediation. Egalitarian and cablaka characterics of Banyumas people will ease the mediation process. Each party feels proportional and not feel superior than others. Habit to speak as it is would facilitate the search for alternative dispute resolution because they used to express their heart honestly. If the agreement has been reached then the dispute parties will try to keep what has become the collective agreement, as how the principle of pareng cidra ora ing ubaya (must not break promise) which is in ponco waliko.

Third, mini trail. This mini trial procedure is quite simple and seems to be able to fulfill the needs of the parties in dispute so that the process can be made accommodative. The parties at first expressed their intention by saying that they are agree to hold this process completely with the procedure. This Agreement is more specialized, including verification mechanism, neutral advisor election (the judge), the exchange of information and the privacy of the procedure. In simple terms this process includes 3 (three) steps: verification process, information exchange, and finally discussion about the matter of dispute resolution. ${ }^{16}$

Fourth, early neutral evaluation. The resolution of dispute based on the local wisdom, so the role of legal practitioners are as the mediator or the judge of the peace of the village.The experience and knowledge of these figures will help will help on giving views to the dispute parties. Traditional leaders, scholars or jus-tice of the village peace are important because they are given with full trust. People who earn the trust of the parties in the dispute will be the driving force that enables the parties on imple-menting the decision. The parties in the dispute would feel embarrassed when they reneged on the decision that has been agreed together. If there is one party who denies the result of a joint decision, then it would appear sanctions, both traditional and social sanctions.

Fifth, settlement conference. The model of settlement conference is the most often model done in the resolution of dispute based on lo-cal wisdom. The shape of Settlement Conferen-ce is in the form of personal approaching in ad-vance with the disputing parties. The approach generally uses indigenous language and religious language to ease the

16 Indriati Amarini, "Penegakan Hukum Pidana Melalui Mediasi (Alternatif Solusi Penanganan Kasus-Kasus Tindak Pidana Ringan", Jurnal Kosmik Hukum, Vol. 10 No. 1 January 2010, Purwokerto: Faculty of Law, Universitas Muhammadiyah Purwokerto, page 28. 
process. This approach is done personally to one of the party without be-ing known by other party before the discussion process which involves both parties along with other wider parties. Based on the principles adopted by the society, such as principle in pon-co waliko, so the process becomes easy to do be-cause it comes from the same thoughts princip-le.

\section{Mechanism of Pancasila Based Dispute Settle- ment Based on Local Wisdom}

Indonesian law could not be denied is strongly influenced by the colonial law which has the character of continental Europe, which does not fit with the character of the Indonesian. Colonial patterned law considered to be expired. It requires legal development in accordance with the current situation and the condition.

There are a few key points which should guide the development of law, including: first, the law is tend to be nurturing/protecting all the people and the homeland of Indonesia, based on unity in order to achieve social justice for all Indonesian people; second, the law should be able to achieve social justice for all Indonesian people; third, the law comes from the people and has populist nature, or in other words there is existence of principle of popular sovereignty; and fourth, the law is based on the value of almighty God, which provides the basic regulations for the laws of God, besides keeping the values of humanity, morality, and noble character. ${ }^{17}$

First mechanism when there is a dispute within the community is to do discussion automatically. The characteristic of Banyumas people who like to talk frankly often makes the discussion process going tough and not able to find a solution in the end. Second mechanism that goes then is to request a third party (mediator) which is selected based on the agreement of both parties in the dispute. The third party is neutral, respected and has authority to help re- solving the dispute. Here, the mediator is more to help the parties to communicate with each other in order to obtain mutual consent. The mediator also has role to relieve anger, frustration, and preventing confrontation.

Third mechanism is to form a sort of judicial institutions which has similarities with the real formal court proceeding in a more modest level. Usually, acting as the judge of the peace is the head of the village although it is possible led by religious leader and public figure.

Fourth mechanism is the decision execution. The execution of judgment is made when the resolution of disputes are achieved. Another interesting thing which deserves to be recorded in the dispute resolution system based the local wisdom is in the execution step. Execution of decision result which has been taken is more adhered and actually followed with heartfelt (sincere). It becomes interesting because when we compare it with similar process on formal judicial or litigation path, largely mediation process conducted almost never been succeed. Even according to records obtained from the District Court of Banyumas and Purwokerto, less than $1 \%$ of cases are successfully resolved through mediation. Other example cases which are often encountered are the dispute parties only won the case on paper but fails in the execution of the verdict. This is the difference between the resolution of dispute by considering the living law, with the formal judicial.

\section{Conclusion}

The concept of local wisdom on its description is an underlying foundation for the establishment of the dispute resolution system without ignoring the principle of Pancasila, which is the source of all sources of law in Indonesia. The dispute resolution system has a structure and mechanism that accommodates law living in the society (the living law) with the local wisdom as its basic. The assumption that the local wis-

17 Kuat Puji Prayitno, "Pancasila sebagai Screening Board dalam Membangun Hukum di Tengah Arus Globalisasi Dunia yang Multidimensional", Jurnal Dinamika Hukum, Vol. 11, Special Edition of February 2011, Purwokerto: Faculty of Law, Universitas Jenderal Soedirman, page 163. 
dom is considered weak, in fact it is more able to accommodate justice without causing friction in the society.

\section{Recommendation}

The wealth of local wisdom which is owned by the society on solving dispute requires follow-up effort on applying the values of local wisdom in the integrated formal legal system from the village up to the Centre. It requires the recognition and institutional strengthening of alternative dispute resolution which starts from the lowest level.

\section{References}

Adisarwono, et.al. 1985. Riwayat Banyumas. Salatiga: Tiga Serangkai;

Amarini, Indriati. "Penegakan Hukum Pidana melalui Mediasi (Alternatif Solusi Penanganan Kasus-Kasus Tindak Pidana Ringan". Jurnal Kosmik Hukum, Vol. 10 No.1 January 2010. Purwokerto: Faculty of Law, Universitas Muhammadiyah Purwokerto;

Arba, Galang Asmara \& Maladi, Yanis. "Penyelesaian Konflik Pertanahan Berbasis NilaiNilai Kearifan Lokal di Nusatenggara Barat". Mimbar Hukum, Vol. 22 No. 1 February 2010. Yogyakarta: Faculty of Law Universitas Gadjah Mada;

Dimiyati. "Penyelesaian Konflik Pertanahan di Provinsi Lampung". Jurnal Keadilan Progresif, Vol. 2 No. 2 September 2011. Yogyakarta: Faculty of Law Universitas Gadjah Mada;

Fitriani, Riska. "Penyelesaian Sengketa Lahan Hutan melalui Proses Mediasi di Kabupaten Siak". Jurnal Ilmu Hukum, Vol. 3 No.1 2012. Riau: Faculty of Law Universitas Riau;

Ilyas, “Kajian Penyelesaian Konflik Antar Desa Berbasis Kearifan Lokal di Kabupaten Sigi, Sulawesi Tengah". Jurnal Academika, Vol. 06 No. 01 February 2014. Palu: Faculty of Social and Political Sciences Universitas Tadulako;

Kafiar, Frans P. "Kearifan Lokal Suku Amungme dalam Pengelolaan Sumber Daya Alam dan Lingkungan di Kabupaten Mimika Papua".
Jurnal EKOSAINS, Vol. V No.1 March 2013. Surakarta: Environmental Studies Program Universitas Sebelas Maret;

Prayitno, Kuat Puji. "Pancasila sebagai Screening Board dalam Membangun Hukum di Tengah Arus Globalisasi Dunia yang Multidimensional". Jurnal Dinamika Hukum, Vol. 11 Special Edition of February 2011. Purwokerto: Faculty of Law Universitas Jenderal Soedirman;

Priyadi, Sugeng. "Beberapa Karakter Orang Banyumas". Jurnal Bahasa dan Seni, Year 31 No. 1 February 2003. Malang: Faculty of Letters Universitas Negeri Malang;

"Orientasi Nilai Budaya Banyumas: antara Masyarakat Tradisional dan Modern". Jurnal Humaniora, Vol. 20 No. 2 June 2008. Yogyakarta: Faculty of Humanities Universitas Gadjah Mada;

"Cablaka sebagai Inti Model Karakter Manusia Banyumas". Jurnal Diksi: Jurnal Ilmiah, Bahasa, Sastra dan Pengajarannya, Vol. 14 No.1 September 2007. Yogyakarta: Faculty of Language and Arts Universitas Negeri Yogyakarta;

2013. Sejarah Mentalitas Banyumas. Yogyakarta: Ombak;

Rina, Yulianti \& Maharani Sri. "Penyelesaian Sengketa Informal Berbasis Komunitas Adat Terpencil di Kepulauan Kangean". Jurnal Dinamika Hukum, Vol. 12 No. 2 May 2012. Purwokerto: Faculty of Law Universitas Jenderal Soedirman.

Rosadi, Otong. "Hukum Kodrat, Pancasila dan Asas Hukum dalam Pembentukan Hukum di Indonesia". Jurnal Dinamika Hukum, Vol. 10 No. 3 September 2010. Purwokerto: Faculty of Law Universitas Jenderal Soedirman;

Suprapto. "Revitalisasi Nilai-Nilai Kearifan Lokal bagi Upaya Resolusi Konflik". Jurnal Walisongo, Vol. 21 No.1 May 2013. Semarang: LP2M IAIN Semarang;

Trianton, Teguh. "Estetika Profetik Ahmad Tohari dalam Khazanah Budaya Cablaka". Jurnal Ibda Jurnal Kebudayaan Islam, Vol. 11 No. 2 July-December 2013. Purwokerto: P3M Institut Agama Islam Negeri Purwokerto. 